\title{
REGIONALIZACIJA SLOVENIJE - NEDOKONČANA SIMFONIJA SLOVENSKE GEOGRAFIJE
}

\section{Ivo Piry}

Služba vlade RS za lokalno samoupravo in regionalno politiko

e-mail: ivo.piry@gov.si

Pregledni znanstveni članek

COBISS 1.02

\section{Izvleček}

Prispevek obravnava različne regionalizacije, katerih avtor je akademik prof.dr.Igor Vrišer, ki so bile uporabljene za potrebe poskusov teritorialno upravnih reform, ki od leta 1993 dalje skušajo vzpostaviti ravnovesja med lokalnimi skupnostmi in državo, z uvedbo vmesne, regionalne ravni lokalne samouprave, ki bi omogočila decentralizacijo in prenos dela državnih pristojnosti na regij. Obravnavana so nova razmerja v teritorialni členitvi Slovenije, uveljavljanje regionalnega pristopa ter pomen regionalizacije za ohranitev konkurenčnosti urbanega sistema.

Ključne besede: regionalizacija, teritorialno upravna reforma, regionalni pristop, regionalna politika

\section{REGIONALISATION OF SLOVENIA - NEVER ENDING STORY OF SLOVENE GEOGRAPHY}

\begin{abstract}
The article discusses different regionalisations prepared by prof.dr.Igor Vrišer, that were used in several attempts of administrative territorial reforms, starting from 1993 onwards in establishing balanced relations between local selfgovernment and the national state with the introduction of second tier of regional selfgovernment taht would enable decentralsation and shift of the responsibilities from tha national state down to the regions. The paper deals with new relations in territorial division of the country, the importance of regional approach in preserving competitiveness of sloven urban centres.
\end{abstract}

Key words: regionalisation, administrative territorial reform, regional approach, regional policy 


\section{UVOD}

Deset let po uvedbi lokalne samouprave se v Republiki Sloveniji ponovno postavlja vprašanje, ali je tokrat pravi trenutek za vzpostavitev ravnovesja med lokalnimi skupnostmi in državo, $\mathrm{z}$ uvedbo vmesne, regionalne ravni lokalne samouprave, ki bi omogočila decentralizacijo in prenos dela državnih pristojnosti na regije.

O regionalizacijah slovenskega ozemlja je bilo v različnih strokah povedano že veliko, lahko bi rekli, da skoraj vse, pa vendar se zdi to vprašanje še vedno aktualno. Posebej še, če se osredotočimo na vprašanja teritorialne členitve za potrebe državne uprave in lokalne samouprave. Med vzroki za oblikovanje teh regionalizacij lahko izpostavimo predvsem težnjo po oblikovanju oziroma utrditvi določene prostorske organizacije človekovih dejavnosti v pokrajini, s katero želimo zagotoviti čimbolj učinkovito in racionalno povezovanje različnih razvojnih dejavnikov prostoru. Poleg tega se v Sloveniji kot mladi državi postavlja v ospredje tudi politični vidik regionalizacije, saj zadeva temeljna vprašanja organizacije države in njene enotnosti ob uvajanju decentralizacije.

V Sloveniji obstaja tradicionalna delitev na večje in manjše pokrajine v zavesti prebivalstva, tudi na podlagi narečnih značilnosti slovenskega jezika. Vendar je zadnjih dvajset let večina predlaganih regionalizacij vezana na koncept policentričnega razvoja urbanega sistema, ki je nastal v 70.letih, v času socialističnega planskega gospodarstva, ki pa je kljub poudarjeni vlogi oblikovanja gravitacijskih območij in hierarhije mest ter razmeščanja prebivalstva in delovnih mest povzel značilnosti poselitvenega vzorca Slovenije, ki izhaja iz geografske členjenosti in značilnosti slovenskega prostora in bolj ali manj uspešno določil središčne (vozliščne) točke poselitvenega (transportnega ) sistema. Glede na najnovejše stanje prostorskih planskih dokumentov, ki jih predstavlja Strategija prostorskega razvoja Slovenije, sprejeta poleti 2004, lahko ugotovimo, da je zadnja modificirana verzija tega koncepta še vedno v veljavi.

Prof.dr.Vrišer je sodeloval pri oblikovanju vseh dosedanjih regionalizacij in tudi v letu 2004 nastala predloga za oblikovanje 14 razvojnih regij za vodenje regionalne politike ter koncept policentričnega urbanega sistema v Strategiji prostorskega razvoja Slovenije izhajata iz teoretičnih konceptov regionalizacije, ki jih je prof.dr.Vrišer zasnoval v toku svojega znanstveno raziskovalnega opusa in jih v dolgoletni pedagoški karieri posredoval številnim generacijam geografov, urbanistov in prostorskih planerjev.

Ob visokem jubileju profesorja dr.Vrišerja želim torej prispevati nekaj misli, povezanih z vlogo njegovih teoretičnih dognanj na področju funkcijske klasifikacije naselij v Sloveniji in njim pripadajočih gravitacijskih območij ob pripravi še vedno veljavnega zakona o spodbujanju skladnega regionalnega razvoja, sprejetega leta 1999. Osvetliti želim vlogo regionalizacij (geografskih) pri oblikovanju odločitev, ki so vplivale na okvir izvajanja regionalne politike v Republiki Sloveniji. 


\section{NOVA RAZMERJA V TERITORIALNI ČLENITVI SLOVENIJE}

Proučevanje problematike centralnih naselij in njihovih vplivnih območij, ki so bila osnova za različne regionalizacije, ima v slovenski geografiji že razmeroma dolgo tradicijo. Velika geografska pestrost Slovenije je geografe spodbujala k raziskovanju homogenosti pokrajinskih elementov in poskusom različnih regionalizacij. Prvenstvo imajo naravnogeografske A.Melika (Melik, 1946), sledi jim fiziognomska regionalizacija S.Ilešiča (Ilešič, 1957,1972) in kasneje geografska regionalizacija Slovenije I. Gamsa (Gams, 1983). Družbenogeografske regionalizacije so večinoma funkcijske oziroma nodalne, saj temeljijo na hierarhiji centralnih naselij. Za potrebe družbenega planiranja sta leta 1962 A.Briški in S.Mrzlikar izdelala rajonizacijo gospodarskega prostora SR Slovenije. Konec šestdesetih let je izšlo delo Igorja Vrišerja (1968) o omrežju centralnih naselij v Jugoslaviji, tri leta za tem pa študija, posvečena omrežju centralnih naselij v Sloveniji (Kokole, 1971), ki je podala funkcijsko regionalizacijo slovenskega ozemlja, ki je bila uporabljena tudi kot podlaga za oblikovanje planskih regij $\mathrm{v}$ regionalnem prostorskem planiranju. Ta problematika je bila na ravni celotne Slovenije ponovno obravnavana v drugi polovici osemdesetih let (Vrišer, 1988; Vrišer, 1990). Razvoj v zadnjem desetletju, ki je prinesel predvsem spremembe na socialnoekonomskem področju (tržno gospodarstvo, privatizacija) in politične spremembe na področju lokalne samouprave, so vnesli nova razmerja v funkcionalno členitev slovenskega ozemlja.

\section{Slika 1: Pokrajine v Sloveniji}

Figure 1: Regions in Slovenia

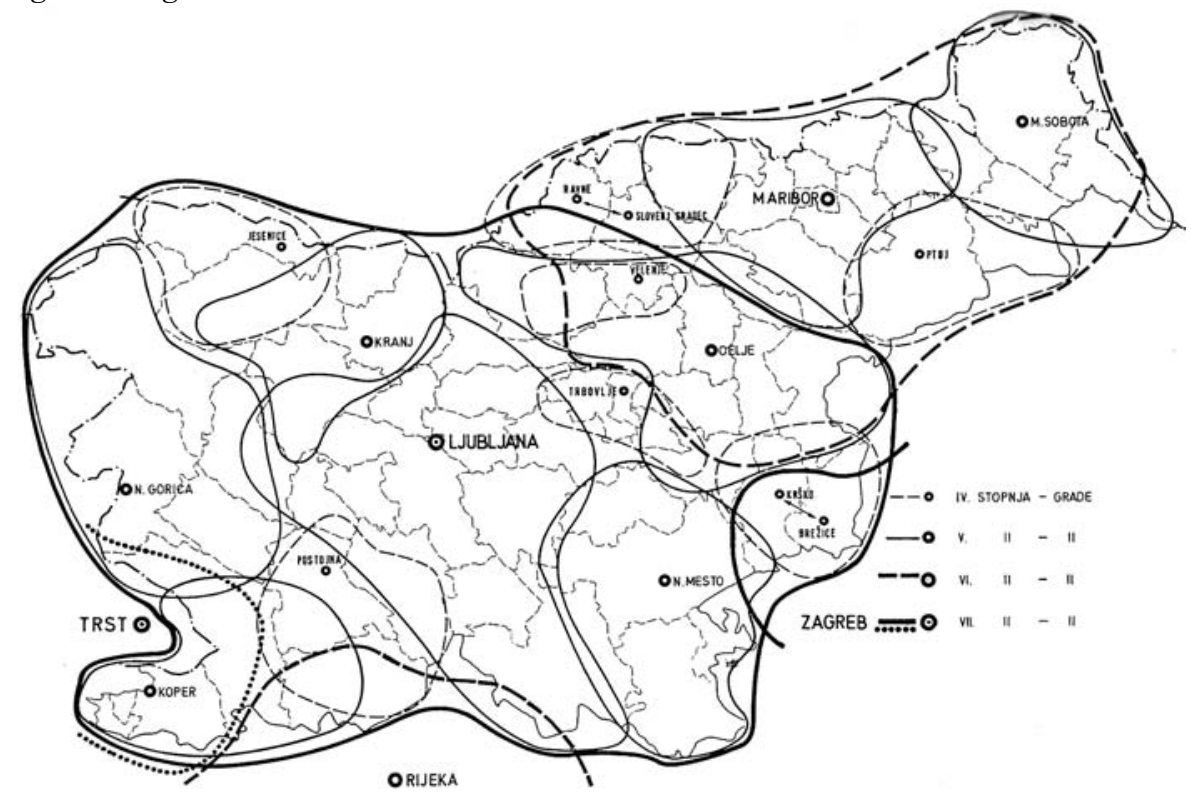

Vir: Vrišer, 1999 
Zato je potrebno poseči nazaj, v čas reforme lokalne samouprave in državne uprave v letu 1993, ko so potekale strokovne diskusije o uveljavitvi različnih modelov lokalne samouprave in reformi državne uprave. Tedaj nastanejo strokovno izjemno skrbno pripravljeni predlogi teritorialne členitve Slovenije, vendar so opozorila oz. zavedanja, da pretirana drobitev na številne male občine lahko pomeni dolgoročno oviro za uvajanje druge ravni lokalne samouprave, prezrta s strani politike. Prof.dr.Vrišer je za Komisijo za lokalno samoupravo Državnega zbora Republike Slovenije poleti 1993 pripravil teze za formiranje upravnih okrajev, kjer je med drugim zapisal, da nastanek novih manjših občin terja vzpostavitev vmesnih upravnih enot med republiško oblastjo in občinsko samoupravo, kar naj bi postali upravni okraji. Poleg tega poudarja, da bo z ustavo predvideno prostovoljno združevanje občin v pokrajine mogoče izvesti šele po formiranju občinske lokalne samouprave, medtem pa potrebe javne uprave narekujejo čimprejšnjo uvedbo upravnih okrajev, pri čemer bi bilo ustrezno, ko bi se pokrajine in okraji teritorialno ujemali. V tezah navaja tudi kriterije za oblikovanje upravnih okrajev, ki naj bi se oprlo na ustrezno število prebivalcev, policentrično zasnovo Republike Slovenije, gravitacijo in navezanost prebivalcev na določena regionalna središča (urbani sistem), na opremljenost teh središč s potrebnimi dejavnostmi (funkcijami) ter na interese posameznih upravnih služb. Opozarja tudi na upoštevanje izkušenj drugih evropskih držav in dežel pri oblikovanju širših lokalnih skupnosti in državne uprave.

Osnovno vodilo pri oblikovanju okrajev bi po njegovem mnenju morala biti spoznanja, ki so se izoblikovala v raziskavah omrežja in hierarhije centralnih naselij in ki za Slovenijo ugotavljajo sedem stopenj središč. Upravni okraji bi sodili na raven 4. - 7. stopnje (mezo in makroregionalna središča). Kljub temu meni, da je Slovenijo po prirodni zgradbi, kot po historičnem razvoju in gravitaciji prebivalstva ter središčem razmeroma težko vsestransko zadovoljivo razdeliti na večje upravne enote. Zanimiva je tudi misel, da bi tedaj predvideno ohranjanje upravnih storitev na nekdanjih občinskih središčih (62), ob nastanku številnih novih občin (leta 1994 jih je bilo ustanovljenih 147), narekovalo oblikovanje večjih upravnih okrajev. Vendar je bilo že tedaj očitno, da bo najprej potrebno sprejeti odločitev, glede oblikovanja malih ali velikih upravnih okrajev, nato pa izbirati med posameznimi inačicami, šele po tej obči odločitvi pa bo treba pretehtati še vsak primer posebej.

Policentrični koncept urbanega razvoja nikoli ni zaživel v vseh dimenzijah, pri čemer mislimo na uveljavitev hierarhije mest, podprte z ustrezno hierarhijo javnih funkcij. Že ob nastanku ga je "nadomestilo" uveljavljanje enakopravnosti in enakovredne opreme nekdanjih občinskih središč /sedanjih sedežev upravnih enot z enakim naborom javnih funkcij. V zadnjih petnajstih letih pa je policentrični koncept, s pojavom suburbanizacije, doživel povsem neuravnoteženo krepitev najvišjih hierarhičnih nivojev, kar je seveda posledica ustrezne kritične mase za hiter razvoj koncentracije prebivalstva in delovnih mest na območju ljubljanske metropolitanske regije ter negativnih učinkov strukturnega prilagajanja gospodarstva $\mathrm{v}$ večini preostalih urbanih središč.

V okviru raziskave Omrežje naselij in prostorski razvoj Slovenije, katere naročnik je bilo Ministrstvo za okolje in prostor, Urad Republike Slovenije za prostorsko planiranje je skupina raziskovalcev pod vodstvom dr.M.Ravbarja in ob sodelovanju prof.dr.Vrišerja proučila omrežje centralnih naselij in njihovih vplivnih območij oziroma ugotavljala sedanje stanje ter spremembe, do katerih je prišlo v zadnjem obdobju. Pri tem je za ugotavljanje obsega vplivnih 
območij posameznih središč uporabila metodo prof.dr. Vrišerja $(1988,1990)$, ki je temeljila na anketiranju krajevnih skupnosti oziroma krajevnih uradov. Z upravnimi spremembami v Sloveniji (pretežna ukinitev krajevnih skupnosti kot obveznih skupnosti na najnižji lokalni ravni) takšen način ni bil več mogoč. Zato so uporabili anketiranje osnovnih šol (podobno je storil že Kokole, 1971), saj omrežje šol oziroma šolskih okolišev zadovoljivo pokriva ozemlje celotne Slovenije, poleg tega pa učitelji na šolah pogosto sodijo med boljše poznavalce lokalnih razmer. (Ravbar et al.,2000)

Slika 2: Predlog regionalizacije za potrebe teritorialno upravne reforme leta 1993

Figure 2: Proposal of regionalisation for territorila adminsitrative reform 1993

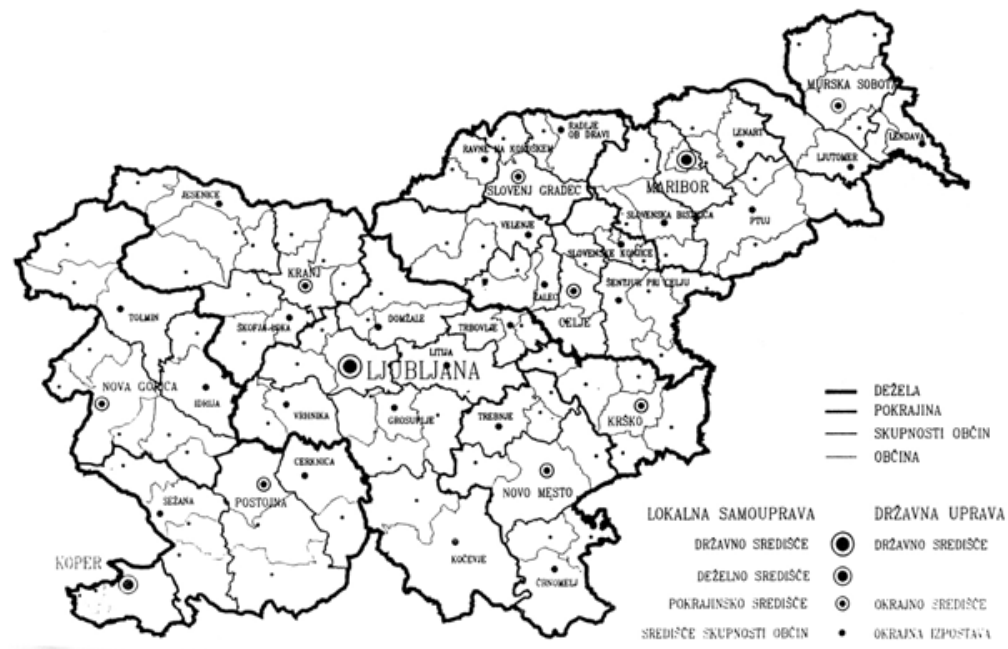

Vir: Piry, Košak, 1993

V primerjavi z ugotovitvami izpred več kot desetletja navaja citirana raziskava, da na nivoju makroregionalnih centrov ni opaziti pomembnejših razlik, se je pa z okrepitvijo vloge Ljubljane kot državnega centra, v katerem se je skoncentriralo veliko število raznovrstnih dejavnosti, okrepila tudi njena vloga kot makroregionalnega središča, kar se odraža zlasti v povečanju območja, ki je pod delnim (ne prevladujočim) vplivom Ljubljane. Položaj na mezoregionalni ravni centralnosti v primerjavi z letom 1987 ni bistveno drugačen. Opazna je razmeroma šibka vloga in s tem manjše vplivno območje nekaterih mezoregionalnih središč (Postojne, Velenja, Trbovelj), prepletanje vpliva različnih središč, ki se s svojo opremljenostjo oziroma storitvami dopolnjujejo (Krško - Brežice, Ravne na Koroškem - Slovenj Gradec) ter velik pomen središč, kot so Koper, Nova Gorica, Kranj, Novo mesto, Celje in Murska Sobota. Kljub novim mejam občin je še zmeraj opazen vpliv "tradicionalnih" povezav, ki imajo v večini primerov, poleg tradicije, tudi druge, pomembnejše temelje, na primer prostorsko bližino ali časovno dostopnost. 
Poselitveni vzorec oziroma koncept razvoja omrežja naselij je potrebno ovrednotiti tudi $\mathrm{z}$ okoljskega vidika. Tudi v Sloveniji so zlasti mesta in mestna naselje generator gospodarskega in družbenega razvoja ter hkrati velik porabnik prostora (pozidava), energije in surovin, proizvajalec številnih trdih, tekočih in plinskih emisij, ki prispevajo k globalnemu, prekomejnemu, regionalnemu in lokalnemu obremenjevanju okolja in zmanjševanju samočistilnih sposobnosti. Ker so zlasti mesta (gospodinjstva in dejavnosti) tudi v Sloveniji temeljni vir degradacije pokrajine in njenih sestavin ter porabnik naravnih virov, je okolju in naravnim virom bolj prilagojena razmestitev in organizacija mestnega materialnega življenja pomemben, verjetno ključni vzvod za zmanjševanje okoljskih pritiskov, saj posredno vpliva tudi na vse ostale vire okoljskih pritiskov, zlasti na promet (Plut, v Ravbar e tal, 2003)

\section{UVELJAVITEV REGIONALNEGA PRISTOPA}

S sprejemom Zakona o spodbujanju skladnega regionalnega razvoja v letu 1999 se je Slovenija opredelila za pomoč regijam in občinam, ki zaostajajo v razvoju. Sprejeti podzakonski akti in Strategija regionalnega razvoja Slovenije so natančno opredelili ta območja. Regionalna politika torej deluje na celotnem območju države, še posebej aktivno pa na prednostnih območjih, kot so:

- regije z najnižjo stopnjo razvitosti (Pomurska, Podravska, Zasavska in Posavska).

- območja s posebnimi razvojnimi problemi. (i) ekonomsko šibka območja, (ii) območja $\mathrm{s}$ strukturnimi problemi in visoko brezposelnostjo in (iii) razvojno omejevana obmejna območja in območja z omejenimi razvojnimi dejavniki. Skupno gre za 129 občin, 57.2\% ozemlja in $48.7 \%$ prebivalstva Slovenije.

- obmejna območja;

- območja na katerih živita madžarska in italijanska narodna skupnost ter romska etnična skupnost;

Priprava regionalnih razvojnih programov, ki je potekala v obdobju 2000 do 2003 pomeni, poleg postopnega uveljavljanja ciljev in institucij zakona o spodbujanju skladnega regionalnega razvoja, nadaljnjo krepitev omrežja dvanajstih statističnih regij. V več regijah se pri tem pokaže notranja diferenciacija in pripadnost novih občin mnogo ožjim identitetam, kot jih predstavljajo statistične regije. Nastajajo različne oblike »mrežnih« povezav, zlasti na območju Goriške, Gorenjske in Obalno kraške regije. Pojavi se tudi zastoj v pripravi regionalnega razvojnega programa $v$ Podravski regiji, kjer se soočamo s pojavom konkurence dveh urbanih središč, Maribora in Ptuja. Tudi to nasprotje je preseženo z mrežno organizacijo šele v letu 2003. Vendar se že v istem letu, ko so se pričele aktivnosti za pripravo novega predloga zakona o spodbujanju skladnega regionalnega razvoja, soočamo z delitvijo dveh statističnih regij - Savinjske in Podravske. Težnje po osamosvojitvi zgornjega dela Savinjske doline in Šaleške kotline, s priznanjem ustrezne vloge Velenja, se pokažejo tudi na zborovanju slovenskih geografov, ki skoraj izzveni kot podpora oblikovanju nove Sa-Ša regije. Prav tako v Spodnjem Podravju diskusije ob pripravi novega zakona oživijo zahteve po oblikovanju samostojne regije s središčem na Ptuju. Predlog zakona, ki predlaga uveljavitev nove delitve Slovenije na 14 razvojnih regij je sprejet na Vladi Republike Slovenije, vendar v nadaljevanju 
postopka doživi podobno usodo kot še vedno veljavni zakon, saj Državni zbor zaradi bližajočih se volitev v letu 2004, odloži obravnavo in prepusti odločanje novemu sklicu parlamenta.

Slika 3: Razdelitev Slovenije na razvojne regije

Figure 3: Division of Slovenia into development regions

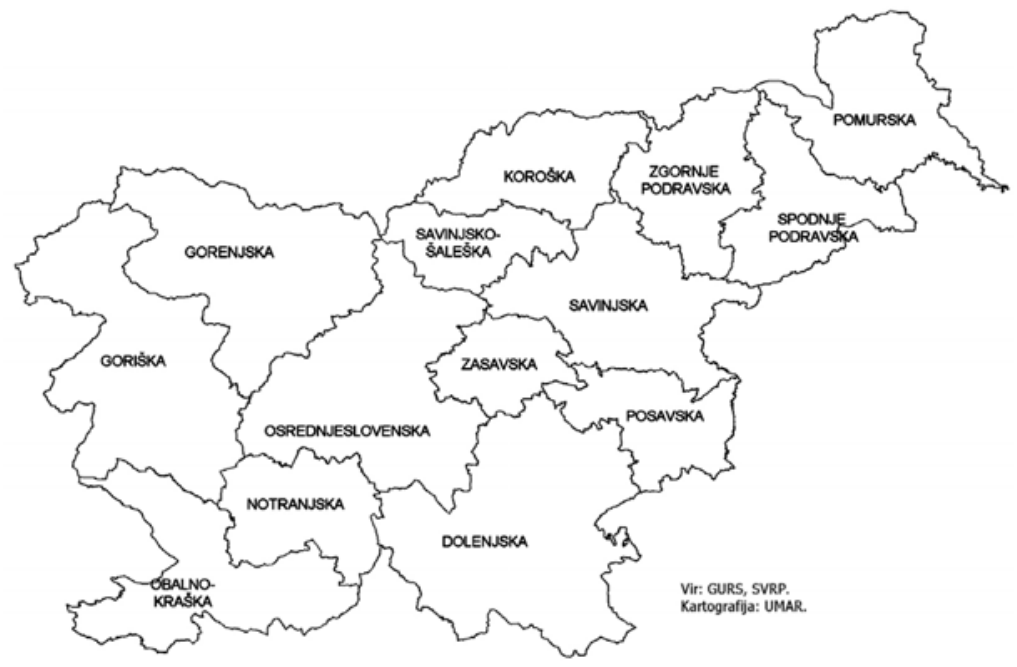

Vir: Predlog zakona o spodbujanju skladnega regionalnega razvoja, 2004

Podpora uveljavljanju regionalnega vidika pri uresničevanju ciljev strategije gospodarskega razvoja Slovenije je močno odvisna od usklajenosti različnih resornih politik, ki v večjem delu podpirajo zgolj horizontalne prioritete posameznega resorja. Proces vključevanja Republike Slovenije v EU je tudi na področje oblikovanja in izvajanja regionalne politike vplival z uveljavitvijo načel evropske strukturne politike, kot so koncentracija, programiranje, partnerstvo, subsidiarnost itd. Novi zakon o spodbujanju skladnega regionalnega razvoja iz leta 1999 dejansko pomeni uzakonitev teh načel, hkrati pa uveljavlja regionalne razvojne programe na ravni statističnih regij kot osnovne razvojne dokumente, za izvajanje celovite razvojne politike. Cilji tako zasnovane regionalne politike so zmanjševanje razvojnega zaostanka Slovenije in slovenskih regij za povprečjem Evropske unije, dvig konkurenčnosti Slovenije in slovenskih regij, doseganje visokega življenjskega standarda in kvalitete življenja ter boljšega zdravja prebivalcev vseh slovenskih regij, pospeševanje razvoja okolju prijaznega gospodarstva ter oblikovanje vseslovenskega gospodarskega razvojnega pola $\mathrm{z}$ dobro prometno povezavo regionalnih središč.

Zavedanje pomena integralnega pristopa in s tem povezovanja ekonomskih, socialnih in prostorskih vsebin razvoja je prisotno v vseh dokumentih razvojnega načrtovanja v Republiki Sloveniji. V Strategiji gospodarskega razvoja Slovenije (SGRS) - Slovenija v EU - je posebno poglavje namenjeno vprašanjem regionalnega razvoja kot integracije vseh treh vidikov razvoja. Osnovni cilj strategije je povečevanje blaginje prebivalcev in prebivalk Slovenije, pri 
čemer gre za uravnovešeno celoto gospodarske, socialne in okoljske sestavine blaginje. Temu Strategija regionalnega razvoja Slovenije dodaja še cilj spodbujanja skladnega regionalnega razvoja oziroma usmeritev v policentrični razvoj države. Medtem ko je SGRS krovni strateški dokument, ki opredeljuje smernice gospodarskega razvoja Slovenije do leta 2006, je Državni razvojni program (DRP) njen izvedbeni dokument. Osnovna cilja DRP 2001-2006 sta: (i) zmanjšanje gospodarskega zaostanka Slovenije napram povprečju EU in (ii) zaustavitev povečanja razlik med slovenskimi regijami na SKTE-2 ravni. Doseganje cilja socialne in ekonomske kohezije z razvitimi evropskimi državami v sedanjih razmerah sicer zahteva prednostno zniževanje razvojnega zaostanka na področju gospodarstva, vendar pa doseženo tako, da se ne bodo poslabšali dosežki na področju socialnega in okoljskega razvoja. Poleg gospodarske, socialne, prostorske in okoljske sestavine trajnostnega razvoja državni razvojni program posebej poudarja tudi skladen regionalni razvoj.

Področje regionalnega razvoja je z vidika geografskih vsebin eno od stičišč različnih vsebin, ki jih prinaša članstvo Slovenije v EZ. Enoten notranji trg in štiri svoboščine - prost pretok blaga, kapitala, storitev in oseb, so temelj evropskega povezovanja, ki eni strani krepijo povezanost držav članic, na drugi strani pa zaradi močne konkurence na evropskem trgu posredno vplivajo tudi na regionalne razlike v gospodarski razvitosti. Odprava teh razlik in skladen razvoj vseh delov EZ je glavni cilj regionalne (zdaj kohezijske) politike EZ, ki ni le unija držav, ampak tudi unija regij.

Podporo tem prizadevanjem pomeni tudi Enotni programski dokument za obdobje 20042006, ki predstavlja podlago za koriščenje sredstev evropskih strukturnih in kohezijskega sklada. Poleg povečanja konkurenčnih sposobnosti Slovenije je drugi najpomembnejši cilj gospodarska krepitev regij. Slovenija namerava učinkovito in uspešno uporabiti razpoložljiva sredstva strukturnih skladov EU. Za nadaljnje približevanje EU v ravni ekonomske in socialne razvitosti in - ob tem - za odpravo notranjih razvojnih neskladij Slovenije ima EPD zastavljene naslednje glavne cilje:

- Povprečna letna rast BDP bo višja kot v skupini EU-15, s čimer se bo postopno zmanjšal zaostanek v BDP na prebivalca za povprečjem EU (v letu 2001 je slovenski BDP na prebivalca, izražen v SKM, znašal $70 \%$ povprečja EU);

- Rast zaposlenosti: gospodarska rast se mora odražati tudi v ustvarjanju novih delovnih mest in ohranjanju obstoječih. Skupna ocena kaže, da bo Slovenija ob podpori sredstev strukturnih skladov v programskem obdobju 2004-2006 ustvarila vsaj 4000 (neto) novih delovnih mest;

- Uravnotežen regionalni razvoj: Cilji uravnoteženega regionalnega razvoja se bodo uresničevali s prostorsko (regionalno) usmerjenim pristopom, ki naj zagotovi, da bosta rast BDP in zaposlenosti povečala blaginjo tudi v manj razvitih, pretežno obrobnih regijah. Glavni cilj SRRS (Strategija regionalnega razvoja Slovenije) v obdobju do leta 2006 je preprečevati nadaljnje povečanje regionalnih neskladij, merjenih kot razmerje v BDP na prebivalca (izraženo v SKM) med najbolj in najmanj razvito regijo. Sedanje razmerje, ki se nanaša na leto 2001, znaša 1:1,9.

Spodbujanje skladnega regionalnega razvoja se dodatno zagotavlja skozi upoštevanje prostorske razmestitve posameznih projektov, ob upoštevanju načela prednostne ga usmerjanja sredstev v slabše razvite regije, ki naj bi prejele $60 \%$ vseh razpoložljivih sredstev. 


\section{POMEN REGIONALIZACIJE ZA OHRANITEV KONKURENČNOSTI URBANEGA SISTEMA}

Leta je bila 2004 sprejeta Strategija prostorskega razvoja Slovenije, ki prinaša nekoliko modificiran model policentričnega urbanega koncepta. Strategija opredeljuje funkcijske regije kot vplivna območja središč nacionalnega pomena, ki obsegajo območje s povprečno 150.000 prebivalci in njihov vpliv sega tudi na gravitacijska območja drugih središč nacionalnega ali regionalnega pomena.

Kot središča nacionalnega pomena naj bi se prioritetno razvijala mesta Celje, Kranj, Ljubljana, Maribor, Murska Sobota, Nova Gorica, Novo mesto, Postojna, Ptuj in Velenje ter somestja Brežice - Krško - Sevnica, Jesenice - Radovljica, Koper - Izola - Piran, Slovenj Gradec - Ravne na Koroškem - Dravograd in Trbovlje - Hrastnik - Zagorje ob Savi.

Slika 4: Strategija prostorskega razvoja Slovenije

Figure 4: Strategy of spatial development of Slovenia

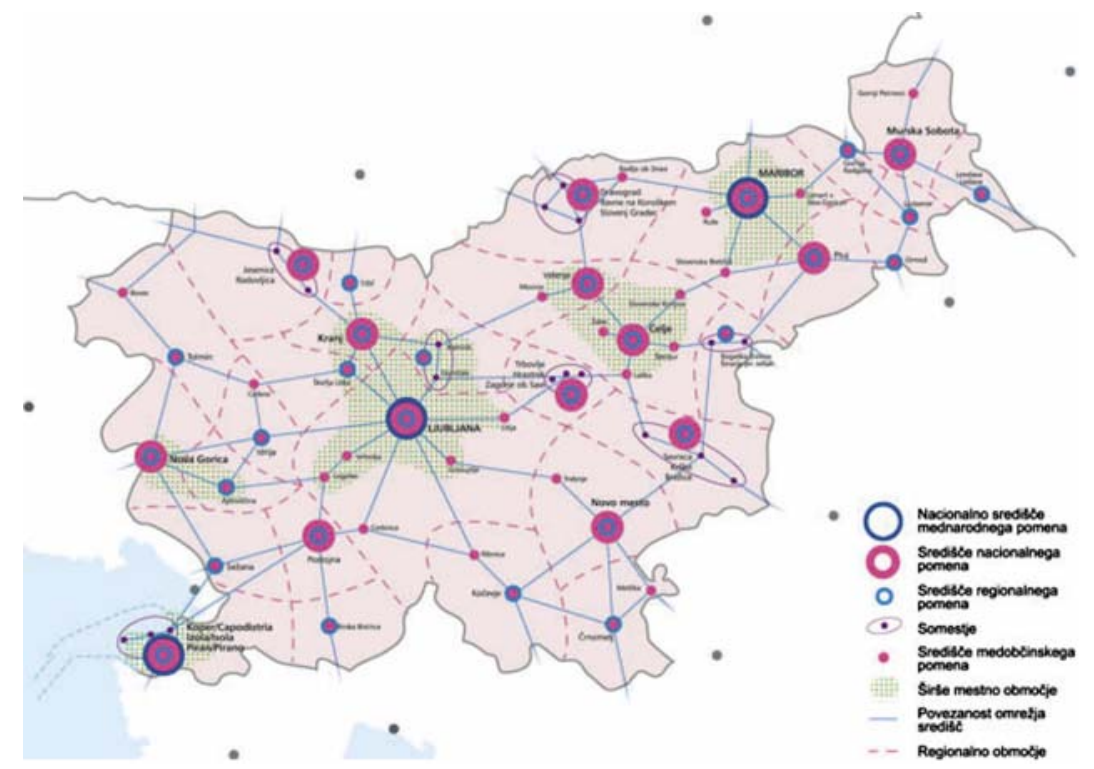

Vir: MOP, 2004

Tradicionalne raziskave, ki so analizirale pomen regionalne opremljenosti in prikazovale gospodarsko strukturo, ponudbo storitvenih dejavnosti, prisotnost visoko produktivnih razvojno-raziskovalnih dejavnosti, prometno povezanost, kvaliteto življenjskega okolja, so nadomestili novi pogledi vrednotenja odnosov znotraj urbane regije. V številnih dokumentih je poudarjeno povezovanje znanstveno-tehnoloških centrov z ostalimi gospodarskimi omrežji, kar ima pomembne prostorske posledice na razvoj omrežja mest na regionalni ravni. S tega vidika predstavlja nosilno ogrodje slovenskega urbanega sistema približno trinajst mestnih 
aglomeracij, kjer okoli petintrideset mest (različne velikosti in družbeno-ekonomskega pomena) skupaj s svojimi obmestji in bližnjimi urbaniziranimi naselji oblikujejo mestne regije. Skupaj zavzemajo petino ozemlja republike. V njih pa prebiva več kot dve tretjini prebivalstva. Tu je po ocenah osredotočene več kot štiri petine ekonomske moči (Ravbar, 2003). Zaradi vpetosti slovenskega gospodarstva $\mathrm{v}$ mednarodno delitev dela, rasti pomena multinacionalnih podjetij in krepitvijo novih komunikacijskih sistemov, se širijo funkcionalna prepletanja med vedno večjimi prostorsko zaokroženimi območji, ne oziraje se na politične meje. Regionalni razvoj Slovenije je za to vedno bolj odvisen od vpetosti v omrežje evropskih ekonomij.

\section{SKLEP}

Ob načrtovanju regionalnega razvoja ter oblikovanju ukrepov regionalne politike se vedno znova dotikamo teritorialno-upravne organiziranosti Republike Slovenije, ob kateri se odpira vprašanje geografije kot stroke, ki naj bi poznala odgovore glede števila in velikosti pokrajin v Sloveniji, s katerimi bomo zagotovili trajnostni vidik razvoja na vseh področjih, demografskem, socialnem, gospodarskem in ne nazadnje okoljskem. Nadaljevanje reforme teritorialno administrativne členitve Slovenije bo ponovna priložnost za utrditev regionalizacije z vidika trajnostnega razvoja. Izhodišče bodo različne stroke in med njimi geografi morali iskati v opredelitvi vloge novih tehnologij v sodobnih komunikacijskih tokovih in omejevanju gravitacijskih območij, saj le ta $\mathrm{z}$ uvajanjem spletnega poslovanja postopoma spreminjajo svoje meje, tudi v navidez tako stabilnih območjih kot so mezoregionalna v Sloveniji. Sodobna prometna in komunikacijska sredstva povezujejo vedno večje prostore v izjemno močno gospodarsko in socialno povezana območja. Načela tržnega gospodarstva tudi v tem primeru narekujejo uporabo pravil ekonomije obsega, ki pa lahko doseže svojo učinkovitost seveda tudi v okviru homogenosti razpoložljivih virov in uspešnem trženju paradigme trajnostnega razvoja, s katerim Slovenija ohranja dediščino evropskega poselitvenega vzorca na stiku alpskega, panonskega in mediteranskega sveta. Delitev na regije je zato lahko podrejena funkcionalističnemu principu, ki v sedanjih pogojih omogoča postopno umiritev dezintegracijskih teženj na lokalni ravni. Tu je pomembna vloga države, da oblikuje takšna območja, ki so z vidika obvladljivosti v upravno-administrativnem smislu najbolj racionalna. Verjetno je temu najbliže sedanja organizacija sodstva. Za uveljavitev regij je torej nujna čimprejšnja upravna reforma, ki bo s koncentracijo središč najvišje ravni omogočila utrditev regionalne členitve. Usoda te členitve ostaja še naprej negotova, saj še vedno drži ugotovitev akademika prof.dr.Igorja Vrišerja, ki je v enem od svojih člankov zapisal »Regionalizacija Slovenije še zdaleč ni preprosta naloga« in k temu lahko dodamo, da tudi nikoli dokončana.

\section{Literatura}

Dolgoročni plan SR Slovenije za obdobje od leta 1986 do leta 2000, Zavod SRS za družbeno planiraje, Ljubjana, s. 99.

Kokole, V1., 1971: Centralni kraji v SR Sloveniji. Problemi njihovega omrežja in njihovih gravitacijskih območij. Geografski zbornik, XII. 
Nacionalni program varstva okolja, 1998, Ministrstvo za okolje in prostor RS, Ljubljana, s. 102

Natek, K., Natek, M., 1998: Slovenija, Mladinska knjiga, s. 415.

Piry, I., 1993: Urbani sistem — ogrodje poselitve v republiki Sloveniji. MOP — Urad za prostorsko planiranje. (tipkopis).

Ravbar, M., 1997: Slovene Cities and Suburbs in Transformation (Slovenska mesta in njihova obmestja v preobrazbi). Geografski zbornik, št. XXXVII, Ljubljana, (1997), str. 64-109.

Ravbar, M., 1998: Značilnosti urbanizacije, Geografski atlas Slovenije, DZS, Ljubljana, s. 310-313.

Ravbar, M. et al, 2003: Omrežje naselij in prostorski razvoj Slovenije, Ministrstvo za okolje in prostor, Urad Republike Slovenije za prostorsko planiranje, 2003

Vrišer, I., 1968: Centralna naselja v Jugoslaviji. Ekonomska revija 4, Ljubljana.

Vrišer, I., 1988: Centralna naselja v SR Sloveniji leta 1987. Geografski zbornik, XXVIII.

Vrišer, I., 1988: Policentrizem v Sloveniji. IB — revija za planiranje XXIII, št. 5, Ljubljana, str. 11-17.

Vrišer, I., 1990: Ekonomskogeografska regionalizacija Republike Slovenije (Na podlagi vplivnih območij centralnih naselij in dejavnostne sestave aktivnega prebivalstva). Geografski zbornik, XXX.

Vrišer, I., 1998: Središčna (centralna) naselja. V: Geografski atlas Slovenije. DZS, Ljubljana.

\section{REGIONALISATION OF SLOVENIA - NEVER ENDING STORY OF SLOVENE GEOGRAPHY}

\section{Summary}

Ten years after introduction of local selfgovernment in Republic of Slovenia there is still a debate whether it is the right moment to introduce intermediate level of territorial organisation by establishment of regions, that would force process of decentralisation and speed up transfer of a number of responsibilities from the state to the regions.Strenghtening the pattern of territorial organisation of economic activities in the regions is only one of the rationales of efficient spatial organisation, followed by political dimensions of the process as regards administrative organisation of the state functions.

During last two decades all attempts of regionalisation of Slovenia were bound to the concept of polycentric urban development model, elaborated in late 70 ies in the era of socialist planning system. The concept gave strong emphasis on shaping gravitation areas and hierarchy of towns, based on geographical differentiation of the country and settlement pattern by defining nodes of population and transport network. Basic parameters of the concept still exist also in the newest Strategy of Spatial Development of Slovenia, adopted in 2004.

Prof.dr.Vrišer contributed to all different regionalisations of Slovenia and also the latest one in 2004, that defines 14 development regions based on polycentric urban development 
concept was based on theoretical concepts provided in his scientific reasearch and educational career that gave knowledge to present urban and regional planners of past three decades.

The reform of local selfgovernment and public administration in 1993 was adopted after different discussions about use of possible models for the two closely related areas, but various warnings about the problems deriving from the appearance of too many tiny communities that could became a long term obstacle for the introduction of the second tier of local selfgovernment were neglected by the politicians.

The issue of regional development represents a framework of different geographical contents which came to the fore after accession of Slovenia to EU. Common european market and four main liberties - free movement of goods, capital, services and persons, which form the basis of european integration, are on the one hand strenghtening the cohesion within the $\mathrm{Eu}$, but on the other hand the growing competitiveness influences the differences in the level of development of almost all the regions. Decreasing differences and balanced regional development are in the focus of regional policy in Slovenia, that is badsed on the network of twelve develoment regions.

Continuation of the reform of territorial administrative division of Slovenia again give opportunity for inclusion of principles of sustainable development. Starting point for all different sciences, among them also for geography should become the definiton of the role of new technologies in communication patterns of gravitation that brings instability even in terms of rigid mezogravitational areas in Slovenia. 